\title{
ZBTB20 wt Allele
}

National Cancer Institute

\section{Source}

National Cancer Institute. ZBTB20 wt Allele. NCI Thesaurus. Code C134024.

Human ZBT B20 wild-type allele is located in the vicinity of 3q13.31 and is approximately $833 \mathrm{~kb}$ in length. This allele, which encodes zinc finger and BT B domain-containing protein 20 , may be involved in transcriptional regulation. Mutation of the gene is associated with Primrose syndrome. 